\title{
The role of antibodies to peripheral nerve antigens in pathogenesis and laboratory evaluation of immune- mediated neuropathies
}

\author{
Evgenija Mihajloska ${ }^{1}$, Ana Poceva Panovska ${ }^{1}$, Katerina Brezovska ${ }^{1}$, \\ Marija Pendovska ${ }^{2}$, Arben Taravari $^{3}$, Ljubica Suturkova $^{1}$ \\ ${ }^{1}$ Faculty of Pharmacy, Ss. Cyril and Methodius University in Skopje, Mother Theresa 47, \\ 1000 Skopje, Republic of North Macedonia \\ ${ }^{2}$ University Clinic for Hematology, Ss. Cyril and Methodius University in Skopje, \\ Mother Theresa 47, 1000 Skopje, Republic of North Macedonia \\ ${ }^{3}$ Universiy Clinic for Neurology, Faculty of Medicine, Ss. Cyril and Methodius University in Skopje, \\ 50 Divizija 6, 1000 Skopje, Republic of North Macedonia
}

Received: October 2021; Accepted: November 2021

\begin{abstract}
Detection of antiganglioside autoantibodies and their association with clinically defined subtypes implicate an autoimmune mechanism of peripheraland cranial nerve damage in peripheral neuropathies.

Increased titer of antibodies that react with human peripheral nerve antigens have been reported in patients with motor neuropathy including Guillain-Barré syndrome,chronic inflammatory demyelinating polyneuropathy, multifocal motor neuropathy and sensory motor neuropathy. This study represents review of the data related to increased titers of anti-glucoconjugate antibodies in different autoimmune neuropathies and their correlation with existence of structural homology between bacterial and glycoconjugated structures, as a basis for understanding the immune pathological response to glycoproteins and glycolipids present in the human peripheral nerve as target antigens in autoimmune neuropathies.

Evaluation of presence and increased level of autoantibodies against peripheral nerve antigens could be an important parameter in laboratory evaluation, diagnosis and prognosis of autoimmune neuropathies and contribute in more efficient therapeutic approaches in treatment of these pathological conditions.
\end{abstract}

Keywords: anti-glycoconjugate antibodies, anti-ganglioside antibodies, peripheral nerves, autoimmune neuropathies

\section{Introduction}

Peripheral neuropathies are heterogeneous group of diseases affecting peripheral nerves, occurring as a component of several common and many rare diseases which diverse in pathology and varying in severity. Peripheral neuropathies are characterized by motor,

\footnotetext{
*emihajloska@ff.ukim.edu.mk
}

sensor or autonomic dysfunctions. Several different types of autoimmune diseases can cause autoimmune neuropathies and produce symptoms of nerve pain and nerve damage. According to their etiology, peripheral neuropathies are divided in two groups: hereditary neuropathies, mainly dysmyelinating and acquired neuropathies, mainly demyelinating neuropathies with autoimmune origin (Martyn and Hughes, 1997). Inflammatory neuropathies include several syndromes 
with different pathological and clinical features including Guillian-Barré syndrome(GBS) and its variants (motor, sensory and Miller-Fisher syndrome (MFS)), chronic inflammatory demyelinating poliradiculoneuropathy (CIDP) and Multifocal motor neuropathy (MMN) (Dalakas, 2013).

The most typical acute autoimmune neuropathy is Polyradiculoneuritis acuta known as Guillain-Barré syndrome. It has been established that GBS is an inflammatory demyelinating polyneuropathy in which the T-lymphocytes and the macrophages attack the peripheral nerves (Prineas, 1981). Moreover, studies have proven that GBS is usually preceded by respiratory, as well as gastrointestinal infections, with following pathogens Hepatitis C, Mycoplasma, Campylobacter jejuni (C.jejuni), Cytomegalovirus(CMV), Epstein-Barre virus $(E B V)$, but can also occur after surgery, injuries, or may be associated with malignant diseases (Yuki, 1997). Much additional knowledge has been gained from additional studies where according to the histologic characteristics GBS is classified in demyelinating and axonal subtypes: acute inflammatory demyelinating polyneuropathy (AIDP) and acute motor axonal neuropathy (AMAN), both associate with antibodies to gangliosides on the axolemma that target macrophages to invade the axon at the node of Ranvie (Hughes and Cornblath, 2005; Kuwabara and Yuki, 2013; Yuki and Hartung, 2012).

Chronic inflammatory demielynating neuropathy (CIDP) is demyelinating autoimmune polyneuropathy which is characterized by the presence of number of different antibodies to the constituents of the peripheral nerve and presence of the antiganglioside antibodies in patient serum (Willison and Yuki, 2002).

Other autoimmune neuropathies are multifocal motor neuropathy and anti-MAG (myelin-associated glycoprotein) neuropathy and both affect sensory and motor nerves (Herrendorff et al., 2017). In recent study, increased antibody titers against multiple gangliosides have been reported in multifocal acquired sensory and motor neuropathy, possibly implicating immune mechanisms in their pathogenesis (Suturkova et al., 2014).

This review focuses on the correlation of the increased titers of anti-glucoconjugate antibodies in different autoimmune neuropathies and existence of structural homology between bacterial and glycoconjugated structures, as an important parameter for understanding the immune pathological response to glycoproteins and glycolipids present in the human peripheral nerve as target antigens in autoimmune neuropathies.

\section{Autoimmune response to peripheral nerve antigens in autoimmune neuropathies}

Identification and characterization of autoantigens present at the human peripheral nerve represents a great challenge in the field of neuroimmunology, especially in demyelinating disorders. A number of studies indicate that myelin specific proteins present in peripheral nervous system including myelin protein zero (P0), myelinassociated glycoprotein (MAG), peripheral myelin protein 2 (P2), peripheral myelin protein 22 (PMP22) have an important role in myelin formation and in mediating autoimmune peripheral nerve disease (Allen et al., 2005; Gabriel et al., 2000; Hughes and Cornblath, 2005).

The latest investigations are focused on understanding of biology of glucoconjugates present at the peripheral nerve, and their immunological reactivity. There is a considerable cross-reactivity among these antiglycoconjugate antibodies, resulting from shared oligosaccharide epitopes, possibly explaining the overlap in syndromes observed in many affected patients (Suturkova et al., 2014).

Anti-MAG neuropathy is caused by monoclonal IgM auto-antibodies that recognize the carbohydrate human natural killer-1(HNK-1) epitope which is highly expressed on adhesion molecules, such as MAG, present in myelinated nerve fibers (Quarles, 2007). Results from nerve biopsy has also confirmed that anti-MAG neuropathy is characterized with demyelinating lesions and deposits of anti-MAG IgM on myelin sheaths (Lombardi, 2005; Monaco et al., 1990).

Many pathogens associated with the development of GBS, such as C.jejuni,CMV, EBV, Mycoplasma pneumonia and Hemophilusinfluenza, are supposed to share homologous carbohydrate epitopes with peripheral nerve components (Rinaldi, 2013). It was shown that antiganglioside antibodies in serum from patients with GBS recognize galactosyl ( $\beta 1-3) \mathrm{N}$-acetylgalactosamine $(\mathrm{Gal}(\beta 1-3)$ GalNAc) epitope, a carbohydrate determinant shared by several gangliosides (GM1, GD1a, GD1b, GT1b and asialoganglioside GA1), peripheral nerve glycoproteins and glycoconjugate antigens present in bacterial cell wall (Aspinall et al., 1994; Thomas et al., 1989). In line with this finding, high titers of antiganglioside antibodies to GM1, GM1b, GD1a have been found in the serum of a number of patients with AMAN following infection with C. jejuni. (Kusunoki, 2000). Additionally, anti-GQ1b and anti-GT1b antibodies were detected in serum from patients with MFS (Chiba et al.,1993; Chung et al., 2014) while anti-GM1 IgM antibodies were associated with development of MMN (Cats et al., 2010; Willison and Yuki, 2002).

Bacterial lipopolysachharides units are considered to induce the production of anti-ganglioside antibodies, due to the presence of terminal tetrasaccharides, identical to those in the gangliosides GM1, GD1a and Gq1b (Yuki et al., 1993). Later it was suggested that due to molecular similarity the immune response to bacterial oligosaccharides can be diverted to their own neuronal antigens, which strongly explains the pathological point of view of an axonal variant of GBS associated with $C$. jejuni infection (Schwerer et al., 1995). 
Another study demonstrates the possible molecular mimicry between cross-reactive glycoproteins in which was concluded that molecular mimicry may have a potential role in the development of GBS in patients with previous infection with $C$. jejuni (Brezovska et al., 2011). This reactivity indicates on presence of shared epitopes in glycoproteins from the human peripheral nerve and $C$. jejuni (O:19), recognized by PNA and by GM1-positive serum from patient with GBS, associated with $C$. jejuni infection (Brezovska et al.,2011).

In recent study positive reactivity with several Gal(13)GalNAc bearing glycoproteins from human peripheral nerve and from C.jejuni O:19 isolates was shown in serum from patients with MMN (Suturkova et al., 2013). One of these patients had a previous history of $C$. jejuni infection which suggests the possibility that C.jejuni may be also involved in the pathogenesis of MMN (Suturkova et al., 2013). Higher frequency of the presence of antiganglioside and anti-glycoprotein antibodies in patients with MMN compared to healthy controls and to patients with other neuropathies point out their pathogenic significance in the inducing and propagation of the nerve damage and development of neurological symptoms (Suturkova et al., 2014).
The etiological factors of several autoimmune diseases can be mediated by proteins belonging to the HSP (heat shock proteins), a family of highly conserved proteins present in all prokaryote and eukaryote cells (Arispe et al., 2002; Yonekura et al., 2004). Yonekura et al. (2004) showed that GBS patients shared higher IgG antibody titers against several families of HSP (HSP 27, HSP 60, HSP 70) in their cerebrospinal fluid. Immunoreactive proteins present in human peripheral nerve (HPN) tissue were also identified in GBS patients, including HSP, intermediate filaments (vimentin and desmin) and other proteins and enzymes such as troponin/tropomyosin complex and ATP synthase subunit beta and the keratan sulfate proteoglycan, lumican (Loshaj-Shala et al.,2018). These findings suggested that the neuronal autoimmune damage is specifically directed to intermediate neuronal (vimentin) and neuromuscular IF, probably localized nearby cell surface, affording increased accessibility to autoantibodies, and shows that the post-infectious development of GBS may be also associated to additional concomitant immune factors that lead to nerve damage generated by auto-immune trigger(s) different from molecular mimicry (LoshajShala et al., 2018).

Table 1. Target antigens and class of antibodies involved in immune-mediated neuropathies and their clinical features

\begin{tabular}{|c|c|c|c|}
\hline Clinical features & $\begin{array}{l}\text { Class of antibody } \\
\text { (immunoglobulin) }\end{array}$ & Antigen & Reference \\
\hline $\begin{array}{l}\text { Anti-MAG } \\
\text { neuropathy }\end{array}$ & IgM & MAG & $\begin{array}{l}\text { Quarles, 2007; } \\
\text { Monaco et al., 1990; } \\
\text { Lombardi, 2005. }\end{array}$ \\
\hline GBS & IgG and IgM & $\begin{array}{l}\text { GM1, GD1a, GD1b, GT1b } \\
\text { and GA1 }\end{array}$ & $\begin{array}{l}\text { Thomas et al., } 1989 . \\
\text { Aspinall et al., 1994; } \\
\text { Brezovska et al.,2011. }\end{array}$ \\
\hline GBS & $\operatorname{IgG}$ & $\begin{array}{l}\text { HSP (HSP 27, HSP 60, HSP } \\
70)\end{array}$ & $\begin{array}{l}\text { Yonekura et al., } 2004 . \\
\text { Loshaj-Shala et al.,2015. }\end{array}$ \\
\hline AMAN & $\operatorname{IgG}$ & GM1, GM1b, GD1a & Kusunoki, 2000; \\
\hline MFS & $\operatorname{IgG}$ & GQ1b & $\begin{array}{l}\text { Chiba et al.,1993; } \\
\text { Chung et al., } 2014 .\end{array}$ \\
\hline MMN & $\operatorname{IgM}$ & GM1 & $\begin{array}{l}\text { Cats et al., 2010; } \\
\text { Willison and Yuki, 2002; } \\
\text { Suturkova et al., 2013; }\end{array}$ \\
\hline
\end{tabular}

AMAN, acute motor axonal neuropathy; GBS, Guillain-Barré syndrome; MAG, myelin-associated glycoprotein; MFS, Miller Fisher syndrome. 
The positive correlation with disease remission in two patients with GBS carrying the highest HSP 70 concentrations, although limited to a low number of patients, are supportive of a peripheral neuroprotective role of extracellular HSP 70, in good accordance to the results from several studies reported in the literature (Loshaj-Shala et al.,2015). Target antigens and class of antibodies involved in immune-mediated neuropathies and their clinical features are summarized in Table1.

\section{Laboratory evaluation of autoimmune peripheral neuropathy}

There are several approaches in diagnosis of patients with peripheral neuropathy including laboratory testing, electrodiagnostic studies, nerve biopsy or even cerebrospinal fluid analysis. A systematic approach begins with clinical history and neurological examination (type of nerve fiber involvement and distribution of symptoms), identification of the underlying etiology and exclusion of potentially treatable causes (Lehmann et al.,2020).

Until recently no standardized tools for the determination of antiganglioside autoantibodies were available. Enzyme immunoassays with highly purified gangliosides have been introduced in the routine diagnostic of peripheral neuropathy but the determination of antibody profiles with this method is not cost-effective. Provided that the optimal binding of gangliosides on membranes can be achieved, dot or line immunoassays may be a good alternative for the multiparametric determination of antiganglioside autoantibodies (Conrad et al., 2007).

Currently, the enzyme-linked immunosorbent assay (ELISA) is a standard immunoassay used in measuring antibody reactivity (expressed as titers) for glycosphingolipids (GSLs) such as gangliosides and sulfoglycolipids in the serum of patients with GBS, variants of GBS, and CIDP. ELISA detects serum antibody binding to ganglioside-coated microwells. The ELISA system, however, requires two days to complete and measures antibodies to individual gangliosides in its present format (Alaedini et al., 2002).

The Bühlmann anti-MAG ELISA is used as the most common and very sensitive platform for MAG testing, but in some cases low and intermediate levels of positivity may not be associated with typical anti-MAG neuropathy (Lunn, 2017).

Human anti-MAG antibodies can be also detected in the patient's serum with Western blots by electrophoresing purified MAG, isolated myelin or whole brain homogenates. Because serum positive for anti-MAG antibodies almost always recognize the SGPG glycolipid, the assay has been performed by certain laboratories using SGPG as antigen instead of human MAG. It is clearly preferable to use MAG instead of SGPG because the IgM antibodies bind to MAG 10-100 times more strongly than to SGPG; consequently, low-affinity anti-MAG antibodies may be missed if SGPG is used as antigen (Dalakas, 2018).

Determination of the level of antibodies against these cross-reactive antigens in serum from patients, may help in the diagnosis of these conditions. Production of monoclonal antibodies against cross-reactive epitopes on glycoconjugates present in human peripheral nerves remain as one of the biggest challenges for development of simple and specific methods for laboratory evaluation of the level of autoantibodies as an important step in diagnostic approaches and prognosis of autoimmune neuropathies.

\section{Conclusion}

Increased titer of antibodies that react with human peripheral nerve antigens have been reported in patients with motor neuropathy including GBS, CIDP, multifocal motor neuropathy and sensory motor neuropathy.

Identification and localization of the GalGalNAc binding glycoproteins and determination of the structure of their immunodominant determinant could help in understanding the mechanisms by which autoantibodies are produced and how they bind to the target antigens on peripheral nerves. Laboratory evaluation of the level of autoantibodies to these cross-reactive glycoprotein antigens could be an added value in diagnosis and prognosis of autoimmune neuropathies.

Resolving the mechanisms which regulate the immune system to produce anti-glycoconjugate antibodies in patients with neuropathies, will give an opportunity to develop specific and effective strategy for targeted immunotherapy in order to prevent or limit the processes that result in autoimmune neuropathy.

\section{References}

Allen, D., Giannnopoulos, K., Gray, I., Gregson, N., Makowska, A., Pritchard, J., Hughes, R.A.C., 2005. Antibodies to peripheral nerve myelin proteins in chronic inflammatory demyelinating polyradiculoneuropathy, J. Periph. Nerve. Sys. 10, 174-180. Available at: https://doi.org/10.1111/j.1085-9489.2005.0010207.x

Alaedini, A., Briani, C., Wirguin, I., Siciliano, G., D’Avino, C., Latov, N., 2002. Detection of anti-ganglioside antibodies in Guillain-Barre' syndrome and its variants by the agglutination assay. Journal of the Neurological Sciences 196, 41-44. Available at: https://doi.org/10.1016/S0022$510 \mathrm{X}(02) 00022-9$

Arispe, N., Doh, M., De Maio, A., 2002. Lipid interaction differentiates the constitutive and stress-induced heat shock proteins Hsc70 and Hsp70. Cell Stress Chaperones 7, 330-338. Available at: https://doi.org/10.1379/14661268(2002)007<0330:lidtca>2.0.co;2

Aspinall, G.O., Armando, G., McDonald, A.G., Pang, H., 1994. Lipopolysachharides of Campylobacter jejuni serotype 
O:19: Structures of $\mathrm{O}$ antigen chains from the serostrain and two bacterial isolates from patients with Guillain-Barre syndrome. Biochemistry 33, 250-255. Available at: https://doi.org/10.1128/iai.62.5.2122-2125.1994

Brezovska, K., PocevaPanovska, A., Grozdanova, A., Suturkova, Lj., Basta, I., Apostolski, S., 2011. Immunoreactivity of glycoproteins isolated from human peripheral nerve and Campylobacter jejuni (O:19).J. Neurosci. Rural. Pract. 2(2), 125-129. Available at: https://doi.org/10.4103/0976-3147.83576

Cats, E.A., Jacobs, B.C., Yuki, N., Tio-Gillen, A.P., Piepers, S., Franssen, H., van Asseldonk, J.T., van den Berg, L.H., van der Pol, W.L., 2010. Multifocalmotor neuropathy: association of anti-GM1 IgM antibodies with clinical features. Neurology 75(22), 1961-1967. Available at: https://doi.org/10.1212/WNL.0b013e3181ff94c2

Chiba, A., Kusunoki, S., Obata, H., Machinami, R., Kanazawa, I., 1993. Serum anti-GQ1b IgG antibody is associated with ophthalmoplegia in Miller Fisher syndrome and GuillainBarré syndrome: clinical and immunohistochemical studies. Neurology 43(10), 1911-1917. Available at: https://doi.org/10.1212/wnl.43.10.1911

Chung, T., Prasad, K., Lloyd, T.E., 2014. Peripheral Neuropathy - Clinical and Electrophysiological Considerations. Neuroimaging. Clin. N. Am. 24(1), 49-65. Available at: https://doi.org/10.1016/j.nic.2013.03.023

Conrad, K., Schneider, H., Ziemssen, T., Talaska, T., Reinhold, D., Humbel, R-L., Roggenbuck, D., 2007. A New Line Immunoassay forthe Multiparametric Detectionof Antiganglioside Autoantibodiesin Patients with AutoimmunePeripheral Neuropathies. New York Academy of Sciences 2007. Available at: https://doi.org//10.1196/annals.1398.031

Dalakas, M.C., 2013. Pathophysiology of autoimmune polyneuropathies. La Presse Médicale42(6-2), e181-e192. Available at: https://doi.org/10.1016/j.lpm.2013.01.058

Dalakas, M.C., 2018.Advances in the diagnosis, immunopathogenesis and therapies of IgM-anti-MAG antibody-mediated neuropathies. Advances in Neurological Disorder 11, 1-12, Available at: https://doi.org/10.1177/ 1756285617746640

Gabriel, C.M., Gregson, N.A., Hughes, R.A.C., 2000. AntiPMP22 antibodies in patients with inflammatory neuropathy. J. Neuroimmunol. 104, 139-146. Available at: https://doi.org/10.1016/S0165-5728(99)00269-6

Herrendorff, R., Hänggi, P., Pfister, H., Yang, F., Demeestere, D., Hunziker, F., Frey, S., Schaeren-Wiemers, N., Steck, J.A., Ernst, B., 2017.Selective in vivo removal of pathogenic anti-MAG autoantibodies, an antigen-specific treatment option for anti-MAG neuropathy. Proc. Natl. Acad. Sci. USA 114(18), E3689-E3698. Available at: https://doi.org/10.1073/pnas.1619386114

Hughes, R.A, Cornblath, D.R., 2005. Guillain-Barré syndrome.Lancet 66(9497), 1653-1666. Available at: https://doi.org/10.1016/S0140-6736(05)67665-9

Kusunoki, S., 2000. Antiglycolipid antibodies in Guillain-Barré syndrome and autoimmune neuropathies. Am. J. Med. Sci.319(4), 234-239. Available at: https://doi.org/10.1097/00000441-200004000-00006

Lehmann, H.C., Wunderlich, G., Fink, G.R., Sommer Claudia, 2020. Diagnosis of peripheral neuropathy. Neurol. Res. Pract., 2: 20. Available at: https://doi.org/10.1186/s42466020-00064-2
Loshaj-Shala, A, Poceva-Panovska, A., Brezovska, K., Beretta, G., Suturkova, Lj., Apostolski, S., 2015. Involvement of serum HSP 70 in Guillain-Barré Syndrome: An exploratory study and a review of current literature. Macedonian Pharmaceutical Bulletin, 61(1), 61-67.Available at: https://doi.org/10.33320/maced.pharm.bull.2015.61.01.008

Loshaj-Shala, A., Colzani, M., Brezovska, K., PocevaPanovska, A., Suturkova, Lj., Beretta, G., 2018. Immunoproteomic identification of antigenic candidate Campylobacter jejuni and human peripheral nerve proteins involved in Guillain-Barré syndrome. Journal of Neuroimmunology 317, 77-83. Available at: https://doi.org/10.1016/j.jneuroim.2018.01.006

Lunn, M., 2017. Laboratory tests in neuropathies: Genes, CSF and antibodies. What and when?. 3rdCongress of the European Academy of Neurology Amsterdam, The Netherlands, June 24-27, 2017.

Martyn, C.N., Hughes, R.A., 1997. Epidemiology of peripheral neuropathy. J. Neurol. Neurosurg. Psychiatry 62(4), 310318. Available at: https://doi.org/10.1136/jnnp.62.4.310

Monaco, S., Bonetti, B., Ferrari, S., Moretto, G., Nardelli, E., Tedesco, F., Mollnes, T.E., Nobile-Orazio, E., Manfredini, E., Bonazzi, L., Rizzuto, N., 1990. Complement dependent demyelination in patients with IgM monoclonal gammopathy and polyneuropathy. N. Engl. J. Med.322, 844-852. Available at: https://doi.org/ 10.1056/NEJM199003083221002

Prineas, J.W., 1981. Pathology of the Guillain-Barre' syndrome. Ann. Neurol. 9(Suppl.), 6-19. Available at: https://doi.org/10.1002/ana.410090704

Quarles, R.H., 2007. Myelin-associated glycoprotein (MAG): past, present and beyond. J. Neurochem. 100(6), 14311448. Available at: https://doi.org/10.1111/j.14714159.2006.04319.x

Rinaldi, S., Brennan, KM., Kalna, G., Walgaard, C., van Doorn, P., Jacobs, BC., Yu, RK., Mansson, JE., Goodyear, CS., Willison, HJ., 2013. Antibodies to heteromeric glycolipid complexes in Guillain-Barré syndrome. PLoS One, 8(12), e82337. Availiable at: https://doi.org/10.1371/journal.pone.0082337

Suturkova, Lj., Brezovska, K., Poceva-Panovska, A., Grozdanova, A., Apostolski, K.S.,Basta, I., 2013. Antibodies to Glycoproteins Shared By Human Peripheral Nerve and Campylobacter Jejuni in Patients with Multifocal Motor Neuropathy.AutoimmuneDis. 2013, 728720. Available at: https://doi.org/10.1155/2013/728720

Suturkova, Lj., Brezovska, K., Poceva-Panovska, A., Grozdanova, A., Apostolski, K.S., 2014. Glycoconjugates as target antigens in peripheral neuropathies. Macedonian pharmaceutical bulletin, 60(2), 21-27.

Schwerer, B., Neisser, A., Polt, R.J., Bernheimer, H., Moran, A.P., 1995. Antibody crossreactivities between gangliosides and lipopolysaccharides of Campylobacter jejuni serotypes associated with Guillain-Barré syndrome. J. Endo. Res. 2, 395-403. Available at: https://doi.org/10.1177/096805199600200602

Thomas, F.P., Lee, A.M., Romas, S.N., Latov, N., 1989. Monoclonal IgMs with anti-Gal( $\beta 1-3)$ GalNAc activity in lower motor neuron disease: identification of glycoprotein antigens in neural tissue and cross reactivity with serum immunoglobulins. J. Neuroimmunol. 23,167-174. Available at: https://doi.org/10.1097/00005072-199003000-00001 
Yonekura, K., Yokota, S.I., Tanaka, S., Kubota, H., Fujii, N., Matsumoto, H., Chiba, S., 2004. Prevalence of anti-heat shock protein antibodies in cerebrospinal fluids of patients with Guillain-Barré syndrome. J. Neuroimmunol. 156, 204-209. Available

at: https://doi.org/10.1016/j.jneuroim.2004.07.017

Yuki, N., Taki, T., Inagaki, F., Takahashi, M., Saito, K., Handa, S., Miyatakee, T., 1993. A bacterium lipopolysaccharide that elicits Guillain-Barré syndrome has a GM1 ganglioside-like structure. J. Exp. Med.178, 1771-1775. Available at: https://doi.org/10.1084/jem.178.5.1771

Yuki, N., 1997. Molecular mimicry between gangliosides and lipopolysaccharides of Campylobacter jejuni isolated from patients with Guillain-Barre'syndrome and Miller Fisher syndrome. J. Infect. Dis. 176(Suppl. 2), S150-S153. Available at: https://doi.org/10.1086/513800

Yuki, N., KuwabaraS, .2007. Axonal Guillain-Barré syndrome: carbohydrate mimicry and pathophysiology. J. Peripher. Nerv. Syst. 12(4), 238-249. Available at: https://doi.org/10.1111/j.1529-8027.2007.00153.x

Yuki, N., Hartung, H.P., 2012. Guillain-Barré syndrome. N. Engl. J. Med. 366, 2294-2304. Available at: https://doi.org/ 10.1056/NEJMra1114525

Willison, H.J., Yuki, N., 2002.Peripheral neuropathies and antiglycolipid antibodies.Brain125(12), 2591-2625. Available at: https://doi.org/10.1093/brain/awf272

\title{
Улогата на антитела насочени кон антигени на периферни нерви во патогенезата и лабораториската дијагностика на автоимуни невропатии
}

\author{
Евгенија Михајлоска ${ }^{1}$, Ана Поцева Пановска ${ }^{1}$, Катерина Брезовска $^{1}$, \\ Марија Пендовска ${ }^{2}$,Арбен Таравари ${ }^{3}$, Љубица Шутуркова ${ }^{1}$ \\ I'Фармацевтски факултет, Универзитет „Св. Кирил и Методиј”, Мајка Тереза 47, \\ 1000 Скопје, Република Северна Македонија \\ ${ }^{2}$ Универзитетска Клиника за хематологија, Универзитет „Св. Кирил и Методиј”, \\ Мајка Тереза 47, 1000 Скопје, Република Северна Македонија \\ ${ }^{3}$ Универзитетска клиника за неврологија, Медицински факултет, \\ Универзитет „Св. Кирил и Методиј”, 50 Дивизија 6, \\ 1000 Скопје, Република Северна Македонија
}

Клучни зборови: гликокоњугатни антитела,антиганглиозидни автоантитела,периферни нерви, автоимуни невропатии

Детекцијата на антиганглиозидни автоантитела и нивната поврзаност со клинички дефинирани подтипови имлицираат автоимун механизам на оштетување на периферните кранијални нерви кај периферна невропатија.

Забележан е зголемен титар на антитела кои реагираат со човечки антигени на периферните нерви кај пациенти со моторна невропатија, вклучувајќи Guillain-Barrés синдром, хронична инфламаторна демиелинизирачка полиневропатија, мултифокална моторна невропатија и сензорна моторна невропатија. Овој труд е преглед на литература за зголемен титар на анти-гликокоњугатни антитела во различни автоимуни невропатии и нивната поврзаност со присуство на структурна хомологија помеѓу бактериски и гликокоњугатни структури, како основа на разбирање на имунопатолошкиот одговор на гликопротеини и гликолипиди присутни во човековите периферни нерви како таргет антигени во автоимуните невропатии.

Евалуација на присуство и зголемено ниво на автоантитела насочени кон антигени на периферни нерви може да претставува важен параметар во лабораториска евалуација, дијагноза и прогноза на автоимуни невропатии и да придонесе за терапевтски пристап со поголема ефикасност кај овие патолошки состојби. 